\title{
120-kD Surface Glycoprotein of Pneumocystis carinii Is a Ligand for Surfactant Protein A
}

\author{
P. E. Zimmerman, D. R. Voelker, F. X. McCormack, J. R. Paulsrud, and W. J. Martin II \\ Division of Pulmonary and Critical Care Medicine, Department of Internal Medicine and Department of Pathology, Indiana University \\ School of Medicine, Indianapolis, Indiana 46202; and Department of Medicine, National Jewish Center \\ for Immunology and Respiratory Medicine, Denver, Colorado 80206
}

\begin{abstract}
Pneumocystis carinii is the most common cause of life-threatening pneumonia in immunocompromised patients. In the current study, surfactant protein A (SP-A), the major nonserum protein constituent of pulmonary surfactant, is demonstrated to bind $P$. carinii in a specific and saturable manner. SP-A is surface bound and does not appear to be internalized or degraded by the $\boldsymbol{P}$. carinii organism. Furthermore, SP-A binding to $\boldsymbol{P}$. carinii is time- and calcium-dependent and is competitively inhibited by mannosyl albumin. In the absence of calcium or the presence of excess mannosyl albumin, SP-A binding to $P$. carinii is reduced by 95 and $71 \%$, respectively. SP-A avidly binds $P$. carinii with a $K_{d}$ of $8 \times 10^{-9} \mathrm{M}$ and an estimated $8.4 \times 10^{6} \mathrm{SP}$-A binding sites per $P$. carinii organism, as determined from Scatchard plots. SP-A is shown to bind $P$. carinii in vivo, and a putative binding site for SP-A on $P$. carinii is demonstrated to be the mannoserich surface membrane glycoprotein gp120. These findings suggest that $\boldsymbol{P}$. carinii can interact with the phospholipid-rich material in the alveolar spaces by specifically binding a major protein constituent of pulmonary surfactant. ( $J$. Clin. Invest. 1992. 89:143-149.) Key words: binding • lectin • pneumonia • surfactant apoprotein - AIDS
\end{abstract}

\section{Introduction}

The most characteristic morphologic finding in Pneumocystis carinii pneumonia is the filling of the alveoli with an abundant network of foamy surfactant-like material that encases the $P$. carinii organisms (1-3). The accumulation of this lipid- and protein-rich material in the alveolar spaces likely contributes to the impairment of gas exchange observed in $P$. carinii pneumonia (4). However, the interaction of $P$. carinii with the components of pulmonary surfactant is poorly understood.

Surfactant protein A (SP-A), ${ }^{1}$ a surfactant-associated protein (5), may play a role in surfactant organization and homeostasis. SP-A has been implicated in the adsorption of phospholipid to the alveolar air-liquid interface (6), the in vitro regula-

Address correspondence to W. J. Martin II, M.D., Indiana University School of Medicine, Division of Pulmonary and Critical Care Medicine, 1001 W. 10th St., OPW 425, Indianapolis, IN 46202-28790.

Received for publication 9 January 1991 and in revised form 24 July 1991.

1. Abbreviation used in this paper: SP-A, surfactant protein A.

J. Clin. Invest.

(c) The American Society for Clinical Investigation, Inc. 0021-9738/92/01/0143/07 \$2.00

Volume 89, January 1992, 143-149 tion of surfactant secretion (7-9) and the in vitro uptake of phospholipid by alveolar type II cells (10). In addition, SP-A is recognized as a calcium-dependent lectin with a binding specificity for immobilized mannose, fucose, glucose, and galactose (11).

The predominant surface membrane protein on $P$. carinii is a glycoprotein with an estimated molecular mass of 110-120 kD, known as $P$. carinii gp120 (12). Recent studies suggest that gp120 may serve to mediate attachment of $P$. carinii to the alveolar epithelium (13). P. carinii gp120 is heavily glycosylated with mannose-containing oligosaccharide chains (14) that could function as ligands for SP-A.

In this study, SP-A is demonstrated to avidly bind $P$. carinii both in vitro and in vivo. This binding is saturable, calcium dependent, and carbohydrate specific. Ligand immunoblotting of size-fractionated $P$. carinii membrane proteins demonstrate that SP-A selectively binds the carbohydrate expressed by the mannose-rich gp120. Finally, SP-A binding to $P$. carinii in vivo is verified by immunoblot analysis of $P$. carinii obtained by lung lavage using polyclonal antibody to rat SP-A.

\section{Methods}

Isolation of $P$. carinii. $P$. carinii pneumonia was induced in pathogenfree rats by immunosuppression with dexamethasone and transtracheal inoculation of $P$. carinii organisms as described by Bartlett et al. (15). P . carinii organisms were then harvested by lung lavage as previously described $(16,17)$. $P$. carinii were purified from the lavage fluid by a method adapted from Masur and Jones (18). The lavage fluid was centrifuged $(600 \mathrm{~g}$ for $10 \mathrm{~min})$ to pellet inflammatory and alveolar cells, and the supernatant was saved. The cell pellet was resuspended and cytopreparation smears were made using a cytologic centrifuge (Cytospin II; Shandon Southern Instruments Inc., Sewickley, PA). The cytopreparation smears were stained with Gomori methenamine silver stain (19) and Diff-Quick (Difco Laboratories, Inc., Detroit, MI) stain (20) to confirm the presence of $P$. carinii organisms. Any suspensions found to contain bacterial, fungal, or inflammatory cell contamination were discarded. The supernatant was centrifuged $(2,000 \mathrm{~g}$ for $30 \mathrm{~min})$ and the resulting $P$. carinii pellet was resuspended in HBSS without calcium or magnesium (Gibco Laboratories, Grand Island, NY) plus $0.6 \mathrm{mM}$ EDTA. Examination of this suspension by light microscopy demonstrated $P$. carinii trophozoites to represent $97-98 \%$ of the intact cellular material present. $P$. carinii trophozoites were quantified by the method of Bartlett et al. (21).

$S P-A$ isolation, purification, and iodination. Surfactant protein A was purified by previously described methods (22). Briefly, surfactant was obtained by lung lavage of rats $4 \mathrm{wk}$ after intratracheal instillation of silica in saline. The surfactant was purified as described by Hawgood et al. (6) and delipidated by extraction with $l$-butanol. The butanol-insoluble protein precipitate was separated from the lipids by centrifugation $(2,000 \mathrm{~g}$ for $30 \mathrm{~min})$. The protein was suspended in $5 \mathrm{mM}$ Tris/ $\mathrm{HCl}$ buffer (pH 7.4) and dialyzed against the same buffer at $4^{\circ} \mathrm{C}$ for $36-48 \mathrm{~h}$. The protein suspension was centrifuged $(150,000 \mathrm{~g}$ for $1 \mathrm{~h})$, and the supernatant was collected and then eluted over an affinity 
column of mannose-Sepharose 6B (23). The SP-A bound to the column in the presence of $2 \mathrm{mM} \mathrm{CaCl}_{2}$ was then eluted with $2 \mathrm{mM}$ EDTA. The eluate was further purified and residual EDTA removed by gel filtration over a Bio-Gel A 5-m column (Bio-Rad Laboratories, Richmond, CA). Protein content was estimated using the method of Lowry et al. (24).

${ }^{125} \mathrm{I}-\mathrm{SP}-\mathrm{A}$ was prepared as previously described according to the method of Bolton and Hunter (25). Rat SP-A (1-2 mg) was dialyzed at $4^{\circ} \mathrm{C}$ against a $0.1 \mathrm{M}$ sodium borate buffer ( $\mathrm{pH} 8.5$ ). A 1-1.5-ml aliquot of the SP-A suspension was added directly to an iced Bolton-Hunter Reagent vial (Amersham Corp., Arlington Heights, IL) after the benzene was removed by evaporation under a stream of nitrogen. The reaction mixture was incubated for $30 \mathrm{~min}$ on ice with occasional mixing. Free ${ }^{125} \mathrm{I}$ was removed by dialysis against a $5-\mathrm{mM}$ Tris buffer $(\mathrm{pH}$ 7.4). The specific activity of the ${ }^{125} \mathrm{I}-\mathrm{SP}-\mathrm{A}$ was $31-54 \mu \mathrm{Ci} / \mathrm{mg}$ protein. The purity of the SP-A and ${ }^{125}$ I-SP-A obtained by these methods has previously been demonstrated (22).

Binding of ${ }^{125} I-S P$-A to $P$. carinii. Isolated $P$. carinii were incubated $18 \mathrm{~h}$ in DME (Whittaker MA Bioproducts, Walkersville, MD) supplemented with $0.6 \mathrm{mg} / \mathrm{ml}$ glutamine, $100 \mathrm{U} / \mathrm{ml}$ penicillin, $100 \mu \mathrm{g} / \mathrm{ml}$ streptomycin, $0.5 \mu \mathrm{g} / \mathrm{ml}$ amphotericin $\mathrm{B}, 4 \mu \mathrm{g} / \mathrm{ml}$ gentamicin, $1 \% \mathrm{BSA}$, and 5 mM EGTA (pH 7.4). To prepare $P$. carinii for binding experiments, the $P$. carinii suspension was centrifuged $(2,000 \mathrm{~g}$ for $15 \mathrm{~min})$, the supernatant was discarded, and the pellet was washed once with HBSS containing $2 \mathrm{mM} \mathrm{CaCl}_{2}$ supplemented with $1 \% \mathrm{BSA}\left(\mathrm{HBSS}^{+}\right)$ and finally resuspended in DME plus $1 \%$ BSA to a concentration of 5 $\times 10^{5} P$. carinii organisms $/ \mathrm{ml}$. Binding of SP-A to $P$. carinii trophozoites was quantified using a modification of the method of Proctor et al. (26). Binding assays performed to determine the specific binding of SP-A to $P$. carinii contained $5 \times 10^{4} P$. carinii $(100 \mu \mathrm{l}), 60-1,500 \mathrm{ng}$ ${ }^{125} \mathrm{I}-\mathrm{SP}-\mathrm{A}(10-30 \mu \mathrm{l})$ in sample buffer $(5 \mathrm{mM}$ Tris/HCl and $1 \% \mathrm{BSA}, \mathrm{pH}$ $7.4)$ in the presence and absence of $10 \mu \mathrm{g}$ unlabeled SP-A. The reaction suspension was incubated for $30 \mathrm{~min}$ in an atmosphere of $90 \%$ air and $10 \% \mathrm{CO}_{2}$ at $37^{\circ} \mathrm{C}$. The suspension was spun in a microfuge $(13,600 \mathrm{~g}$ for $2 \mathrm{~min}$ ). The cell pellet was washed one time with $\mathrm{HBSS}^{+}$, and the pellet was added to a $12 \times 75$-mm tube for counting. Counts per minute present were determined using a gamma counter, and the amount of ${ }^{125} \mathrm{I}-\mathrm{SP}-\mathrm{A}$ bound was quantified (ng bound $=\mathrm{CPM}_{\text {pellet }} /$ protein specific activity). To study the effect of time, temperature, calcium, and excess carbohydrate on the binding of SP-A to $P$. carinii, binding assays were performed using $1 \times 10^{6} \mathrm{P}$. carinii in $\mathrm{HBSS}^{+}, 100 \mathrm{ng}{ }^{125} \mathrm{I}-\mathrm{SP}-\mathrm{A}$, and increasing concentrations of calcium $(0-2 \mathrm{mM}), \alpha$-methylmannopyranoside (Sigma Chemical Co., St. Louis, MO) (0-750 mM) and mannosyl-BSA $(0-1,000 \mu \mathrm{g})$ with a molar ratio of mannose to albumin of 26:1 (Sigma Chemical Co., St. Louis, MO). The final volume of the mixture was $160 \mu \mathrm{l}$. The assay was incubated as above and the amount of ${ }^{125} \mathrm{I}-\mathrm{SP}-\mathrm{A}$ bound was quantified (ng bound $=100$ $\times \mathrm{CPM}_{\text {pellet }} /\left[\mathrm{CPM}_{\text {pellet }}\right.$ supernatant $]$ ).

The ability of anti-SP-A IgG to inhibit binding was also examined in a similar manner using $0,1.0$, and $2.5 \mu \mathrm{g}$ of antibody. Polyclonal rabbit anti-rat SP-A IgG was raised in New Zealand white rabbits. The animals were injected with 50-100 $\mu \mathrm{g}$ of purified rat SP-A in Freund's complete adjuvant. A second booster injection of 50-100 $\mu \mathrm{g}$ of rat SP-A in Freund's incomplete adjuvant was given at $14 \mathrm{~d}$. The titer of antibody was assayed $10 \mathrm{~d}$ after the booster injection by ELISA using purified rat SP-A as the solid phase. A repeat booster injection was given in cases where the titer was $<1: 10,000$. Antibody was isolated from immune rabbit serum on Protein-A Sepharose CL-4B (Pharmacia LKB Biotechnology, Inc., Piscataway, NJ) and eluted with $0.1 \mathrm{M}$ acetic acid. The eluted fraction was neutralized immediately in Tris buffer and adsorbed against rat serum bound to Affigel-10 and Affigel15 columns (Bio-Rad Laboratories). The antibody was exhaustively dialyzed against $\mathrm{PBS}$ and stored at $-20^{\circ} \mathrm{C}$. The purity and specificity of this antibody has previously been demonstrated (9).

To examine whether SP-A is surface bound or internalized, binding assays were performed as above at $37^{\circ}$ and at $4^{\circ} \mathrm{C}$, a temperature at which internalization is inhibited. A second method to determine whether ${ }^{125} \mathrm{I}-\mathrm{SP}$-A was surface bound used release of ${ }^{125} \mathrm{I}-\mathrm{SP}$-A from $P$. carinii by washing the cells with $5 \mathrm{mM}$ Tris/HCl plus $5 \mathrm{mM}$ EGTA (pH 7.4). Since the binding of SP-A to $P$. carinii is calcium dependent, this treatment releases surface-bound but not internalized ${ }^{125}$ I-SP-A.

Finally, autoradiography and TCA precipitation of purified and bound ${ }^{125}$ I-SP-A were used to study whether bound SP-A remains intact or is degraded after binding. $P$. carinii bound by ${ }^{125} \mathrm{I}$-SP-A were solubilized in SDS-PAGE sample buffer $(0.125 \mathrm{M}$ Tris, $20 \%$ glycerol, $4 \%$ SDS, $0.002 \%$ bromophenol blue, and $4 \% 2$-mercaptoethanol), and the proteins were size fractionated by SDS-PAGE. The gel was dried and exposed to Kodak X-Omat RP film for $2 \mathrm{~h}$ at $-70^{\circ} \mathrm{C}$. TCA precipitation of purified and $P$. carinii-bound ${ }^{125} \mathrm{I}-\mathrm{SP}-\mathrm{A}$ was done using a TCA final concentration of $26 \%$.

Binding of SP-A to P. carinii membrane proteins. Rat $P$. carinii organisms obtained from culture (27) were solubilized in $9.5 \mathrm{M}$ urea, $2 \%$ (wt/vol) NP-40, $2 \%$ ampholines (composed of $1.6 \% \mathrm{pH}$ range 5-7 and $0.4 \% \mathrm{pH}$ range $3-10$ ) and $5 \% 2$-mercaptoethanol. The $P$. carinii proteins were then electrofocused and size fractionated by two-dimensional gel chromatography as described by O'Farrell (28). To demonstrate whether SP-A binds a $P$. carinii surface protein, the protein in the two-dimensional gel was electrophoretically transferred for $\mathbf{3 0} \mathrm{min}$ to an Immobilon-P PVDF transfer membrane (Millipore Corp., Bedford, MA) using Towbin buffer (29) supplemented with $0.05 \%$ SDS. The membrane was blocked with $3 \% \mathrm{BSA}, 5 \mathrm{mM}$ Tris, $2 \mathrm{mM} \mathrm{CaCl}_{2}, 0.5 \%$ Triton X-100 pH 7.4 (buffer A) for $2 \mathrm{~h}$. The membrane was blotted with $20 \mu \mathrm{g} / \mathrm{ml} \mathrm{SP}-\mathrm{A}$ in buffer A for $2 \mathrm{~h}$ at room temperature. After this, all washes and incubations were done at $4^{\circ} \mathrm{C}$. After each incubation the membrane was washed five times, $5 \mathrm{~min} /$ wash with buffer $A$. The membrane was immunoblotted with $20 \mu \mathrm{g} / \mathrm{ml}$ polyclonal rabbit antibody to rat SP-A for $2 \mathrm{~h}$. The bound SP-A was visualized using horseradish peroxidase-conjugated goat anti-rabbit IgG antibody developed with 4-chloro-1-naphthol in diethylene glycol (Bio-Rad Laboratories).

Demonstration of in vivo binding of SP-A to P. carinii. To demonstrate whether SP-A is bound to $P$. carinii organisms in vivo, organisms were collected as before in lavage fluid containing $2 \mathrm{mM} \mathrm{CaCl}_{2}$. Lung lavage from uninfected animals was obtained and purified in a similar fashion and used as a control. The $P$. carinii obtained from lung lavage were centrifuged $(71,000 \mathrm{~g}$ for $90 \mathrm{~min})$ through a $20-60 \%$ discontinuous sucrose density gradient. The cell band present at the $20-30 \%$ $(0.58-0.88 \mathrm{M})$ sucrose interface was collected and solubilized in SDSPAGE sample buffer. The $P$. carinii and the corresponding control fractions were subjected to SDS-PAGE, transferred to nitrocellulose, and then immunoblotted with rabbit polyclonal antibody to rat SP-A. The presence of SP-A was identified using horseradish peroxidase-conjugated goat anti-rabbit IgG antibody directed against the rabbit polyclonal anti-SP-A antibody.

Statistical analysis. Values are expressed as means \pm SEM. Differences between control and experimental data groups were compared using the one-tailed $t$ test or ANOVA with paired comparisons performed using Fisher's LSD method. Statistical significance was accepted for $P<0.01$.

\section{Results}

${ }^{125}$ I-SP-A binding to $P$. carinii trophozoites. SP-A binds $P$. carinii in vitro in a time-dependent manner and achieves apparent equilibrium by $30 \mathrm{~min}$ (Fig. 1). At $5 \mathrm{~min} 34.45 \pm 0.62 \mathrm{ng}$ ${ }^{125} \mathrm{I}-\mathrm{SP}-\mathrm{A} / 1 \times 10^{6}$ organisms is bound, whereas at the observed times of $30 \mathrm{~min}$ and beyond, mean binding of ${ }^{125} \mathrm{I}-\mathrm{SP}-\mathrm{A}$ plateaus at $52.62 \pm 0.56 \mathrm{ng} / 1 \times 10^{6}$ organisms. Further binding experiments were conducted at $30 \mathrm{~min}$, a time when equilibrium of SP-A binding was established.

The calcium requirement for optimal binding of SP-A to $P$. carinii was examined by repeating the SP-A binding assays in the presence of increasing concentrations of extracellular calcium (Fig. 2). In the absence of calcium only $2.85 \pm 0.27 \mathrm{ng}$ of ${ }^{125} \mathrm{I}-\mathrm{SP}-\mathrm{A}$ is bound, whereas in the presence of $2 \mathrm{mM}$ calcium 


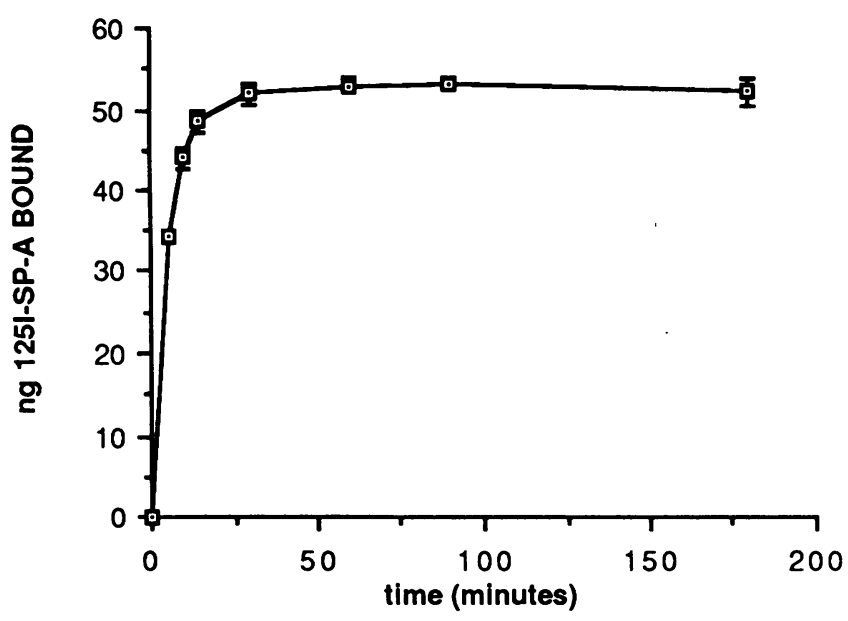

Figure $1 .{ }^{125} \mathrm{I}-\mathrm{SP}-\mathrm{A}$ binds $P$. carinii in a time-dependent fashion. Binding assays were performed using $1 \times 10^{6} \mathrm{P}$. carinii incubated with $100 \mathrm{ng}{ }^{125} \mathrm{I}-\mathrm{SP}-\mathrm{A}$ in HBSS, $2 \mathrm{mM}$ calcium, and $1 \%$ BSA for the indicated times. Binding equilibrium is evident at $30 \mathrm{~min}$, with $51.92 \pm 1.33 \mathrm{ng}{ }^{125} \mathrm{I}-\mathrm{SP}-\mathrm{A}$ bound $/ 1 \times 10^{6}$ organisms. Values are means \pm SEM of three experiments performed in duplicate.

$59.96 \pm 3.05 \mathrm{ng}$ SP-A is bound. Binding appears to plateau beyond calcium concentrations in excess of $1 \mathrm{mM}$ calcium. This is in agreement with previous studies, demonstrating the calcium requirement of SP-A ligand binding (11). Therefore, extracellular calcium appears to also be required for the optimal binding of SP-A to P. carinii.

The specificity and ligand concentration dependence of ${ }^{125}$ I-SP-A binding to $P$. carinii was demonstrated using increasing amounts of ${ }^{125} \mathrm{I}-\mathrm{SP}-\mathrm{A}(60-1,500 \mathrm{ng})$ in the presence and absence of $10 \mu \mathrm{g}$ excess unlabeled SP-A (Fig. $3 A$ ). Addition of increasing amounts of ${ }^{125} \mathrm{I}-\mathrm{SP}-\mathrm{A}$ to the binding assay resulted in an increase in both total and nonspecific binding, with saturation of specific binding evident at concentrations in excess of $1,000 \mathrm{ng}{ }^{125} \mathrm{I}$-SP-A added. Scatchard plots (30) using the specific binding data are linear $(r=0.99)$, indicating a homoge-

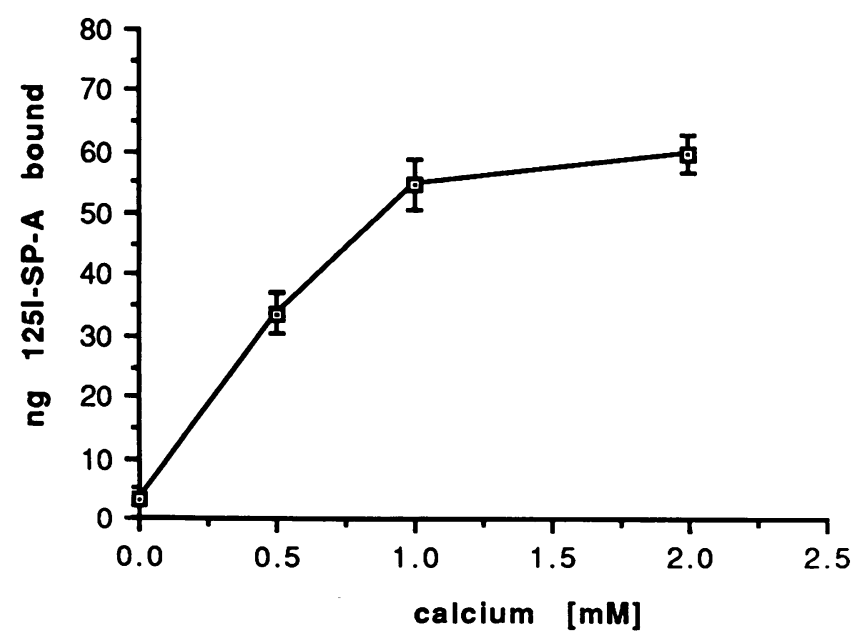

Figure 2. Calcium is required for ${ }^{125} \mathrm{I}-\mathrm{SP}-\mathrm{A}$ to bind $P$. carinii. Binding assays were performed as in Fig. 1, using increasing amounts of extracellular calcium. Maximal binding reveals a plateau at calcium concentrations above $1 \mathrm{mM}$. Values are means \pm SEM of three experiments performed in triplicate.
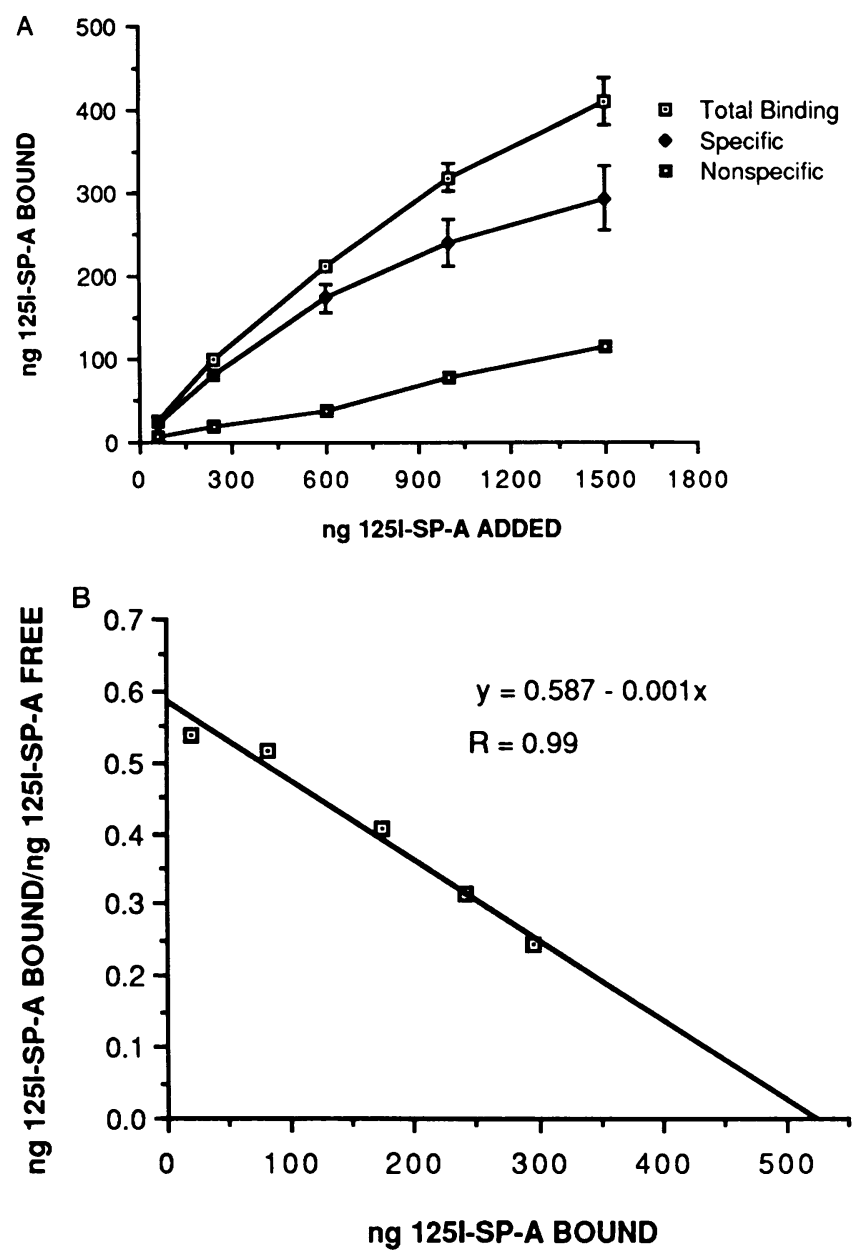

Figure 3. Saturation and specific binding of ${ }^{125} \mathrm{I}-\mathrm{SP}-\mathrm{A}$ to $P$. carinii. Binding assays were performed using $5 \times 10^{4} P$. carinii, $60-1,500 \mathrm{ng}$ ${ }^{125} \mathrm{I}$-SP-A with and without $10 \mu \mathrm{g}$ excess unlabeled SP-A. $(A)$ Saturation of specific SP-A binding to $P$. carinii demonstrated in the presence of $>1,000 \mathrm{ng}{ }^{125} \mathrm{I}-\mathrm{SP}$-A added. Values are means \pm SEM of three experiments performed in triplicate. $(B)$ Scatchard plot of specific binding data. The slope of the line represents a $K_{\mathrm{d}}$ of $8 \times 10^{-9} \mathrm{M}$ for the binding interaction of SP-A and $P$. carinii. The number of SP-A binding sites per organism was calculated from the $x$-intercept to be $8.4 \times 10^{6}$.

nous population of binding sites for SP-A on $P$. carinii (Fig. 3 $B$ ). The binding dissociation constant $\left(K_{\mathrm{d}}\right)$ is $8 \times 10^{-9} \mathrm{M}$, with each $P$. carinii trophozoite estimated to have $8.4 \times 10^{6}$ binding sites for SP-A, using an estimated molecular mass for SP-A of $750 \mathrm{kD}(31,32)$.

$P$. carinii binding of SP-A occurs at the cell surface and does not appear to require active internalization of the SP-A oligomer. Binding of SP-A to $P$. carinii occurs both at $37^{\circ}$ and at $4^{\circ} \mathrm{C}$, a temperature at which membrane vesicle internalization is inhibited (33) (Fig. $4 \mathrm{~A}$ ). Binding is slightly greater at $4^{\circ} \mathrm{C}$ $(71.17 \pm 2.31 \mathrm{ng})$ compared with $37^{\circ} \mathrm{C}(50.03 \pm 2.79 \mathrm{ng})$. Surface binding is further supported by demonstrating that $92 \%$ of ${ }^{125} \mathrm{I}-\mathrm{SP}-\mathrm{A}$ bound at $37^{\circ} \mathrm{C}$ can be removed from $P$. carinii by washing the organisms with $5 \mathrm{mM}$ EGTA (Fig. $4 \mathrm{~B}$ ).

Autoradiography of ${ }^{125} \mathrm{I}-\mathrm{SP}-\mathrm{A}$ bound to $P$. carinii at $37^{\circ} \mathrm{C}$ reveals that SP-A is not degraded. No SP-A fragments are found upon examination of an autoradiogram prepared from an SDS-PAGE of bound ${ }^{125}$ I-SP-A when compared with puri- 

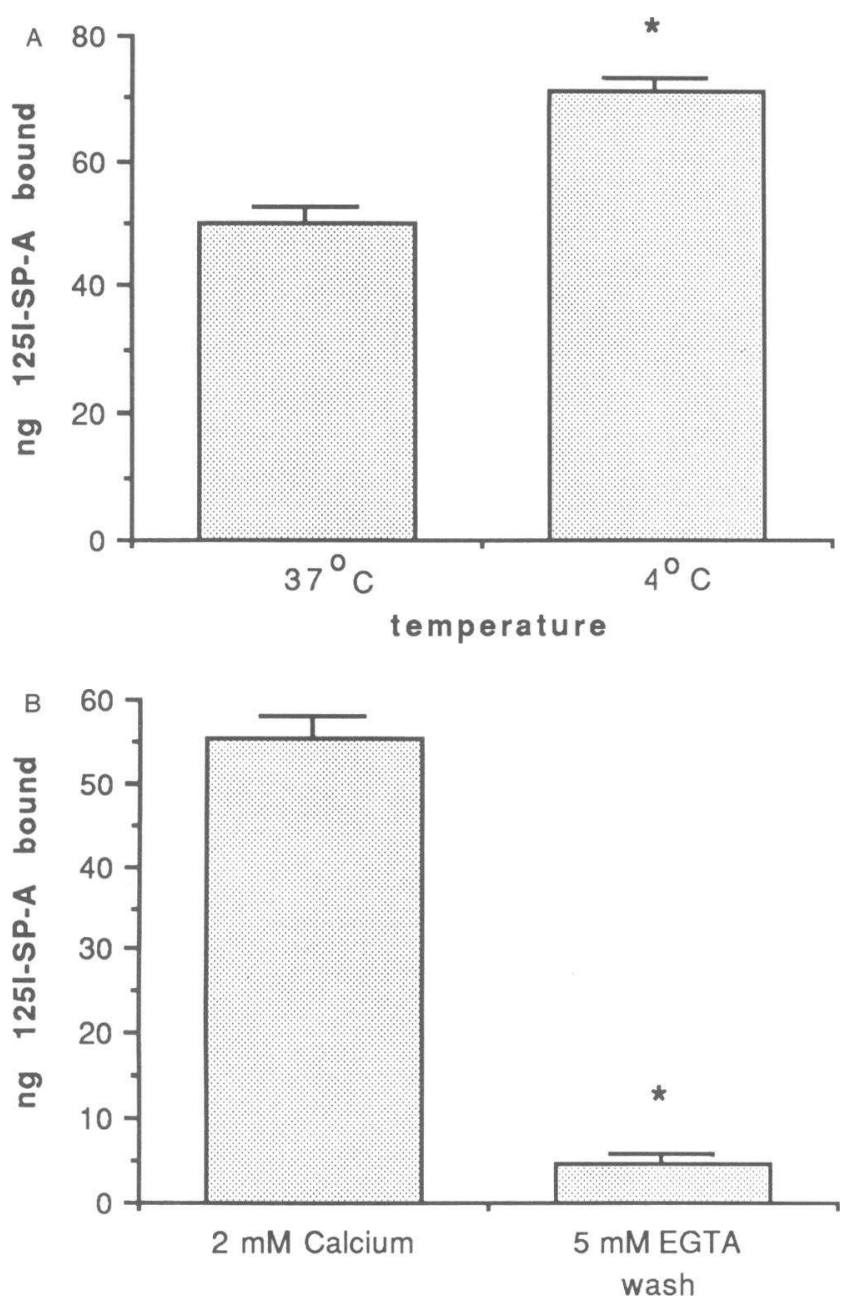

Figure 4. SP-A is bound to the cell surface of $P$. carinii. $(A)$ Binding assays were performed using $100 \mathrm{ng}{ }^{125} \mathrm{I}-\mathrm{SP}-\mathrm{A}$ incubated with $1 \times 10^{6}$ P. carinii for $30 \mathrm{~min}$ in $\mathrm{HBSS}, 2 \mathrm{mM}$ calcium, and $1 \% \mathrm{BSA}$ at $37^{\circ} \mathrm{C}$ and $4^{\circ} \mathrm{C}$. Binding is clearly evident at $4^{\circ} \mathrm{C}$, a temperature at which receptor internalization inhibited. Values are means \pm SEM of three experiments performed in triplicate $\left({ }^{*} P<0.01\right)$. (B) ${ }^{125} \mathrm{I}-\mathrm{SP}$-A bound to $P$. carinii at $37^{\circ} \mathrm{C}$ is nearly completely reversed by washing the organisms in $5 \mathrm{mM}$ EGTA. Values are means \pm SEM of three experiments performed in triplicate $\left({ }^{*} P<0.01\right)$.

fied ${ }^{125}$ I-SP-A (data not shown). Furthermore, there is no difference between the TCA precipitability of purified ${ }^{125}$ I-SP-A compared with the ${ }^{125} \mathrm{I}-\mathrm{SP}-\mathrm{A}$ incubated with $P$. carinii, 94.1 vs. $94.6 \%$, respectively $(P>0.50)$. The failure to show a disparity between these two groups provides evidence supporting the absence of formation of small ${ }^{125}$ I-SP-A peptide degradation fragments by the $P$. carinii organism.

SP-A binding to $P$. carinii could also be inhibited by polyclonal anti-SP-A IgG (Fig. 5). In the absence of antibody $38.40 \pm 3.22 \mathrm{ng}{ }^{125} \mathrm{I}-\mathrm{SP}-\mathrm{A}$ is bound, whereas in the presence of $2.5 \mu \mathrm{g}$ anti-SP-A IgG binding is reduced to $9.77 \pm 2.05 \mathrm{ng}$.

To determine whether SP-A recognized carbohydrates expressed by $P$. carinii surface membrane glycoproteins, ${ }^{125} \mathrm{I}-\mathrm{SP}$-A binding experiments were conducted in the presence and absence of excess carbohydrate. Because $P$. carinii expresses high mannose-type oligosaccharides on its surface (14) and the specificity of SP-A for mannose has been well described (11), $\alpha$-methyl-D-mannopyranoside and mannosyl-BSA were

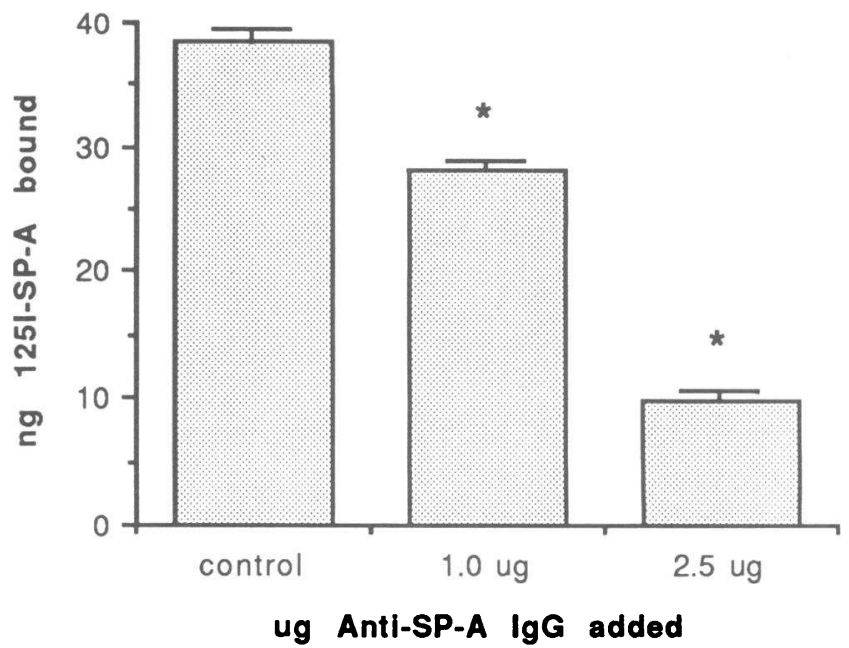

Figure 5. Polyclonal anti-SP-A IgG inhibits SP-A binding to $P$. carinii. ${ }^{125} \mathrm{I}$-SP-A binding assays were performed in the absence and presence of polyclonal anti-SP-A IgG. SP-A binding is inhibited by $75 \%$ using $2.5 \mu \mathrm{g}$ of antibody. Values are means \pm SEM of three experiments performed in triplicate $\left({ }^{*} P<0.01\right)$.

used to determine whether SP-A binding to $P$. carinii exhibited a specificity for carbohydrate. Mannosyl-BSA effectively inhibits ${ }^{125}$ I-SP-A binding to $P$. carinii (Fig. $6 \mathrm{~A}$ ). SP-A binding can be inhibited by $71 \%$ in the presence of $2.42 \mathrm{mM}$ mannose when mannose is presented as the multivalent glycoprotein mannosyl-BSA, whereas the monosaccharide $\alpha$-methyl-Dmannopyranoside (Fig. $6 B$ ) requires concentrations as high as $500 \mathrm{mM}$ to achieve a similar degree of inhibition (73\%). Other monosaccharides known to be ligands for SP-A, such as $N$-acetyl-D-glucosamine also inhibit SP-A binding to $P$. carinii at high concentrations (data not shown). However, there is a limitation to the use of monosaccharides in studying SP-A binding, because the carbohydrate specificity of SP-A decreases as the monosaccharide concentration increases. The ability of low mannose concentrations, in the form of mannosyl-BSA, to inhibit binding of SP-A to $P$. carinii suggests that a glycoprotein expressed by $P$. carinii is a possible ligand for SP-A.

$S P-A$ binding to $P$. carinii membrane proteins. To demonstrate the SP-A target binding site on $P$. carinii, SP-A binding to $P$. carinii membrane proteins was examined by ligand immunoblot analysis. Whole $P$. carinii proteins were resolved by two-dimensional gel chromatography and stained with Coomassie brilliant blue R-250 (Fig. $7 A$ ). Two-dimensional chromatography of $P$. carinii proteins reveal a $116-120-\mathrm{kD}$ basic protein, representing the majority of $P$. carinii surface protein (12) known as gp120.

The immunoreactivity for SP-A present on the ligand immunoblot analysis (Fig. 7 B) demonstrates that SP-A binds the $P$. carinii $120-\mathrm{kD}$ surface glycoprotein, as well as a smaller protein with an estimated mass of $80 \mathrm{kD}$. There is no immunoreactivity for SP-A present when immunoblots are performed with omission of the initial SP-A incubation (data not shown). Ligand immunoblots of $P$. carinii gp120 treated with $50 \mathrm{mM}$ sodium metaperiodate (34), express no immunoreactivity for SP-A (data not shown), demonstrating that oxidation of the carbohydrate residues of gp 120 destroys the epitope required for SP-A binding. The inhibition of SP-A binding to whole $P$. carinii organisms with mannosyl-BSA and the periodate sensi- 

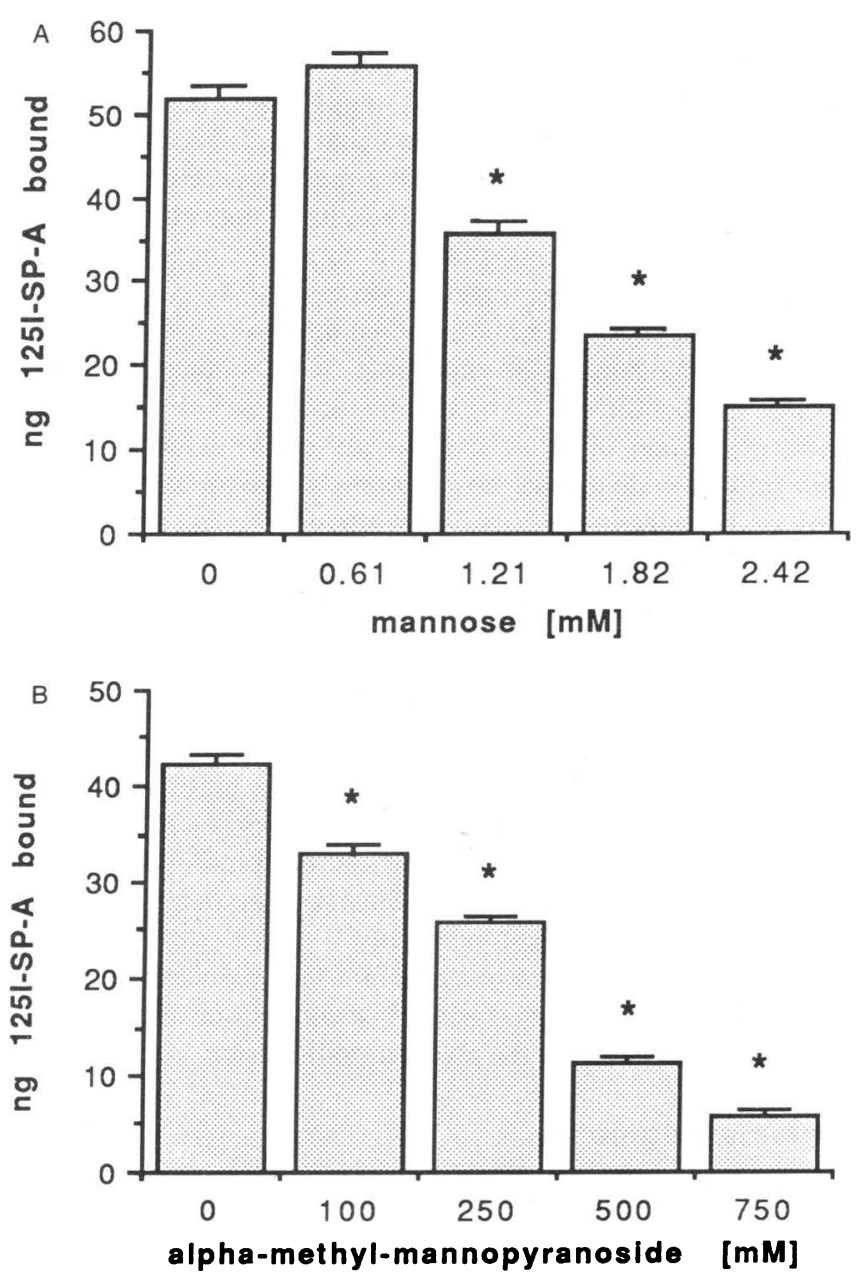

Figure $6 .{ }^{125} \mathrm{I}$-SP-A binding to $P$. carinii is inhibited by excess monovalent and multivalent carbohydrates. $(A)$ Binding assays were performed in the presence of increasing amounts of the multivalent ligand mannosyl-BSA $(0-1,000 \mu \mathrm{g})$, resulting in an increase in monosaccharide concentration $(0-2.42 \mathrm{mM})$. In the presence of $2.42 \mathrm{mM}$ mannose (1 mg mannosyl-BSA), $71 \%$ of ${ }^{125} \mathrm{I}-\mathrm{SP}-\mathrm{A}$ binding is inhibited. There is no inhibition of ${ }^{125} \mathrm{I}-\mathrm{SP}$-A binding observed when identical concentrations of the carrier protein, BSA, are used (data not shown). $(B){ }^{125}$ I-SP-A binding assays were performed in the presence of increasing concentrations of the monosaccharide $\alpha$-methyl-Dmannopyranoside. At the highest concentration tested ${ }^{125} \mathrm{I}-\mathrm{SP}-\mathrm{A}$ binding is inhibited by $86 \%$. Values are means \pm SEM of three experiments performed in triplicate $\left({ }^{*} P<0.01\right)$.

tivity of SP-A binding to $P$. carinii membrane proteins provide strong evidence that SP-A recognizes oligosaccharide moieties of gp1 20.

In vivo demonstration of SP-A binding to P. carinii. Because SP-A binds $P$. carinii in vitro, the pivotal issue is whether similar binding occurs in vivo within the alveolar milieu. In vivo SP-A binding to $P$. carinii was demonstrated by use of immunoblot analysis of $P$. carinii membrane proteins isolated and purified as described above. The immunoblot (Fig. 8) using polyclonal rabbit antibody to rat SP-A demonstrates the specificity of the antibody to purified SP-A (lane 3). Lanes 1 and 4 represent identical immunoreactivity for SP-A found to be present in the isolate of $P$. carinii (lane 1 ) and in $P$. carinii purified from discontinuous sucrose density gradients (lane 4 ). There is no immunoreactivity for SP-A evident in the isolate obtained from pathogen-free rats (lane 2). The absence of immunoreactivity in lane 2 is further evidence that the methods of $P$. carinii isolation from lung lavage does not also co-purify free host SP-A with the $P$. carinii organisms. This experiment provides direct evidence for the in vivo binding of SP-A to $P$. carinii.

\section{Discussion}

P. carinii organisms have previously been demonstrated to avidly bind alveolar surfactant (35); however, the mechanism of adherence between surfactant and $P$. carinii has not been defined. This study indicates that SP-A, the major protein constituent of surfactant, binds $P$. carinii in a specific and saturable fashion. Scatchard plots estimate the number of SP-A binding sites per $P$. carinii organism to be $\sim 8.4 \times 10^{6}$. The linearity of the plots suggest that a homogeneous group of binding sites exist, with a similar affinity for SP-A.

SP-A exists in vivo as a large multivalent oligomeric protein composed of $\sim 18$ subunits, similar to that of complement component Clq (36). Analysis of the deduced primary amino

A
(anode)
1 (cathode)
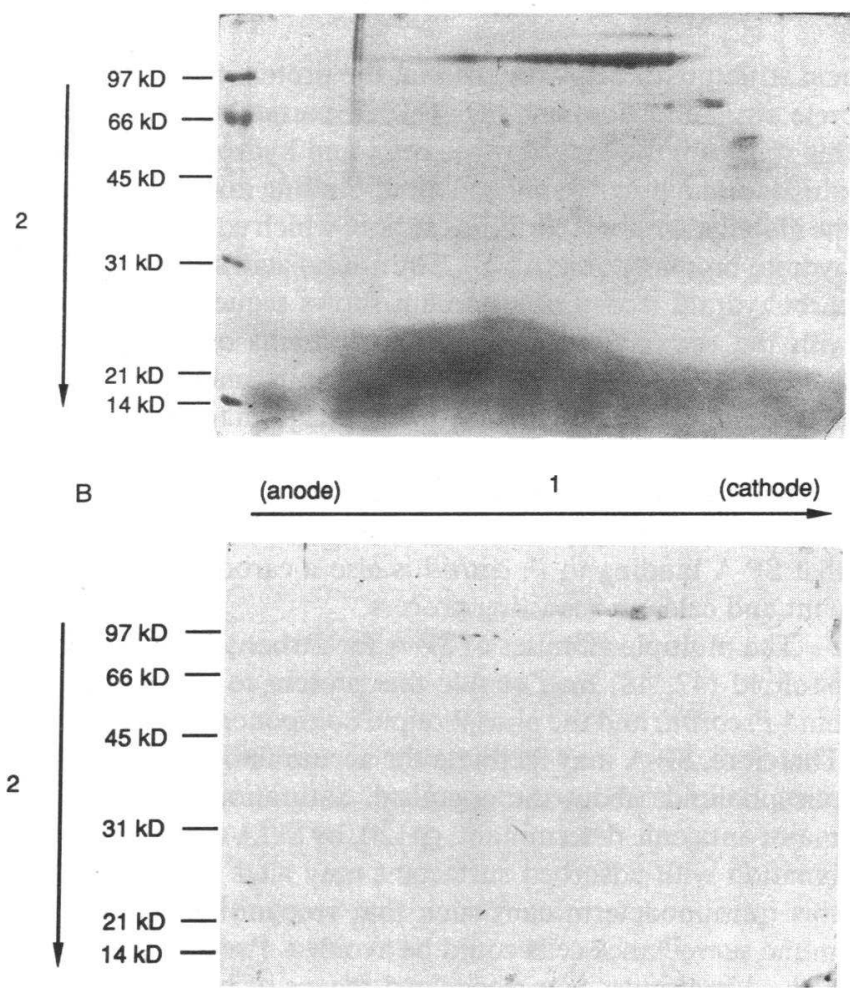

Figure 7. SP-A binds $P$. carinii gp120. (A) Two-dimensional gel chromatography of $P$. carinii proteins. $P$. carinii organisms were electrofocused ( 1 , first dimension) using ampholines with a $\mathrm{pH}$ range of 3 to 10 and then size fractionated by SDS-PAGE (2, second dimension) and stained with Coomassie brilliant blue. The predominate band seen represents $P$. carinii gp120. (B) Ligand immunoblot of SP-A binding whole $P$. carinii proteins. SP-A binds almost exclusively to the protein band corresponding to the mannose-rich cell surface glycoprotein gp120. In addition there is a small amount of immunoreactivity for SP-A present in the $80-\mathrm{kD}$ area representing SP-A binding to a lesser expressed $P$. carinii glycoprotein. 


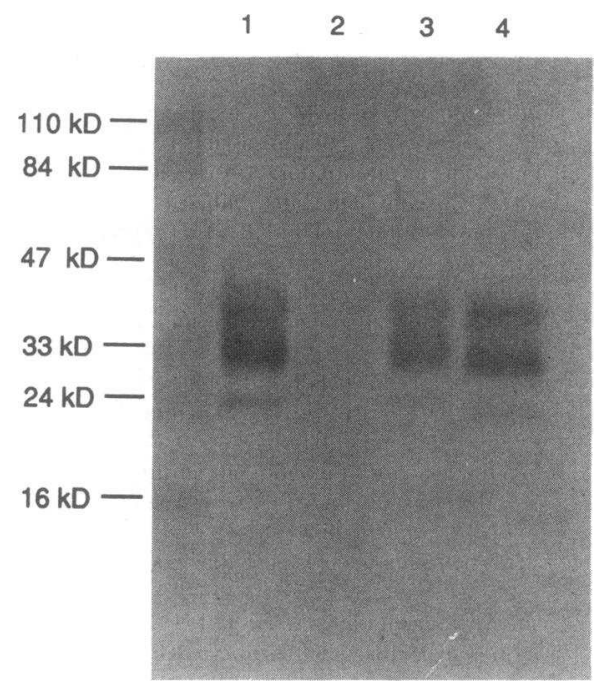

Figure 8. P. carinii binds SP-A in vivo. $P$. carinii membrane proteins were prepared and immunoblotted using polyclonal antibody to rat SP-A as described in the methods. Immunoreactivity for SP-A is demonstrated in the same $26-38 \mathrm{kD}$ range in the $P$. carinii membrane protein preparations (lanes 1 and 4 ) as is visible in the purified SP-A control lane (lane 3). No immunoreactivity for SP-A is evident in lane 2 , representing alveolar lavage proteins prepared from pathogen-free rats in the same fashion as the $P$. carinii proteins.

acid structure of SP-A reveals that the protein has several discrete structural domains (37-41). Of particular relevance to this study are the amphipathic helix and hydrophobic region, which form a putative phospholipid-binding domain (42), and the globular carboxyl terminus region, which contains a carbohydrate-binding domain (43). The amino acid sequence of the carbohydrate recognition domain shows sequence homology with the carbohydrate-recognition domains of other C-type lectins, specifically the soluble serum lectin, mannose-binding protein, and the hepatic and macrophage mannose receptor (43-45). SP-A has previously been shown to require calcium for binding to immobilized saccharides or to its receptor on isolated alveolar type II cells $(22,46,47)$. These data suggest that SP-A binding to $P$. carinii is also a carbohydrate-dependent and calcium-requiring process.

The multiple affinities of SP-A for carbohydrate and phospholipid $(42,48)$ may enable this protein to simultaneously bind $P$. carinii and the phospholipid components of surfactant. Therefore, SP-A may facilitate the accumulation of surfactant phospholipids about the organism. Saturation of $P$. carinii's major antigenic determinant, gp 120, by SP-A alone or in combination with adsorbed surfactant may alter the structure of this immunodeterminant such that recognition by host immune surveillance cells could be avoided. Parasite acquisition of host molecules is a recognized means of host immune response avoidance (49). The interaction of $P$. carinii with SP-A could potentially result in the combined disruption of SP-A's regulatory role of alveolar phospholipid homeostasis and the disorganization of the alveolar phospholipid monolayer, in part explaining the alveolar filling process and hypoxia seen in P. carinii pneumonia (4).

The predominant antigenic determinant on the $P$. carinii cell membrane is the mannose-rich membrane glycoprotein gp120 $(34,50)$. In this study, SP-A is demonstrated to bind $P$. carinii gp120, supporting the hypothesis that gp120 is a putative binding site on $P$. carinii for SP-A. The ability of mannosyl-BSA to inhibit binding of SP-A to gp 120 and the periodate sensitivity of SP-A binding suggests that the SP-A binding is dependent on intact oligosaccharides present on the gp120 ligand. Furthermore, immunoblot analysis of isolated $P$. carinii membrane proteins demonstrates the presence of SP-A, indicating that SP-A is adherent to $P$. carinii in vivo.

$P$. carinii gp 120 has been demonstrated to play a potential role in the mechanism of adherence of the organism to the alveolar epithelium (13). The binding of the carbohydrate recognition domain of SP-A to $P$. carinii in the alveolar lining fluid may provide the organism access to the alveolar epithelium via fibronectin-mediated attachment between SP-A's free collagen-like domain and the alveolar epithelium. This is suggested by fibronectin's ability to bind the collagenous domain of the structurally homologous protein complement C1q (51) and fibronectin's ability to mediate attachment of $P$. carinii to the alveolar epithelium (15).

In summary, this study provides direct evidence that SP-A, the major protein constituent of surfactant, binds $P$. carinii. This binding is specific and saturable, time dependent, carbohydrate specific, and calcium requiring. The binding site on the $P$. carinii organism appears to be the mannose-rich membrane glycoprotein gp 120. The binding of SP-A to $P$. carinii in vivo may enhance adsorption of surfactant to the organism, possibly impede host defenses against $P$. carinii, as well as potentiate $P$. carinii adherence to the alveolar epithelium.

\section{Acknowledgments}

We thank David Smith for his excellent assistance in the purification and iodination of SP-A and Steve Brady for his time in preparation of the two-dimensional gels and PVDF membranes.

This study was supported by National Institutes of Health grants HL-43524 and HL-46647 (W. J. Martin) and HL-29891 (D. R. Voelker). Dr. Zimmerman is the recipient of the Sunnyside Guild Fellowship in Pulmonary Medicine. Part of this work was performed in the Lord and Taylor Laboratory for Lung Biochemistry and the Anna Perahia Adatto Clinical Research Center, Denver, CO.

\section{References}

1. Rifkind, D., T. D. Faris, and R. B. Hill. 1966. Pneumocystis carinii pneumonia. Studies on the diagnosis and treatment. Ann. Intern. Med. 65:943-956.

2. McNeal, J. E., and T. G. Yaeger. 1960. Observations on a case of Pneumocystis pneumonia. Arch. Pathol. 70:397-406.

3. Esterly, J. A., and N. E. Warner. 1965. Pneumocystis carinii pneumonia: twelve cases in patients with neoplastic lymphoreticular diseases. Arch. Pathol. 80:433-441.

4. Van Nhieu, J. T., A. M. Vojtek, J. Bernaudin, E. Escudier, and J. FleuryFeith. 1990. Pulmonary alveolar proteinosis associated with Pneumocystis carinii. Chest. 98:801-805.

5. King, R. J., and J. A. Clements. 1972. Surface active materials from dog lung. II. Composition and physiological correlations. Am. J. Physiol. 223:715726.

6. Hawgood, S., B. J. Benson, J. Schilling, D. Damm, J. Clements, and R. T. White. 1987. Nucleotide and amino acid sequences of pulmonary surfactant protein SP 18 and evidence for cooperation between SP 18 and SP 28-36 in surfactant lipid adsorption. Proc. Natl. Acad. Sci. USA. 84:66-70.

7. Dobbs, G. L., J. R. Wright, S. Hawgood, R. Gonzalez, K. Venstrom, and J. Nellenbogen. 1987. Pulmonary surfactant and its components inhibit secretion of phosphatidylcholine from cultured rat alveolar type II cells. Proc. Natl. Acad. Sci. USA. 84:1010-1014.

8. Rice, W. R., G. F. Ross, F. M. Singleton, S. Dingle, and J. A. Whitsett. 1987. Surfactant-associated protein inhibits phospholipid secretion from type II cells. J. Appl. Physiol. 63:692-698. 
9. Kuroki, Y., R. J. Mason, and D. R. Voelker. 1988. Pulmonary surfactant apoprotein $A$ structure and modulation of surfactant secretion by rat alveolar type II cells. J. Biol. Chem. 263:3388-3394.

10. Wright, J. R., R. E. Wager, S. Hawgood, L. Dobbs, and J. A. Clements. 1987. Surfactant apoprotein $M_{r}=26,000-36,000$ enhances uptake of liposomes by type II cells. J. Biol. Chem. 262:2888-2894.

11. Haagsman, H. P., S. Hawgood, T. Sargeant, D. Buckley, R. T. White, K. Drickamer, and B. J. Benson. 1987. The major lung surfactant protein, SP 28-36, is a calcium-dependent, carbohydrate-binding protein. J. Biol. Chem. 262:13877-13880.

12. Radding, J. A., M. Y. K. Armstrong, E. Ullu, and F. F. Richards. 1989. Identification and isolation of a major cell surface glycoprotein of Pneumocystis carinii. Infect. Immun. 57:2149-2157.

13. Pottratz, S. T., J. Paulsrud, and W. J. Martin II. 1990. Pneumocystis carinii membrane glycoprotein gp 120 is a fibronectin binding protein which mediates Pneumocystis attachment. Clin. Res. 38:466a. (Abstr)

14. Nakamura, Y., K. Tanabe, and K. Egawa. 1989. Structure of major surface determinants and DNA diagnosis of Pneumocystis carinii. J. Protozool. $36: 60$ s-61s.

15. Bartlett, M. S., J. A. Fishman, S. F. Queener, M. M. Durkin, M. A. Jay, and J. W. Smith. 1988. New rat model of Pneumocystis carinii pneumonia. J. Clin. Microbiol. 26:1100-1102.

16. Pottratz, S. T., and W. J. Martin II. 1990. Role of fibronectin in Pneumocystis carinii attachment to cultured lung cells. J. Clin. Invest. 85:351-356.

17. Limper, A. H., and W. J. Martin II. 1990. Pneumocystis carinii: inhibition of lung cell growth mediated by parasite attachment. J. Clin. Invest. 85:391-396.

18. Masur, H., and T. C. Jones. 1978. The interaction in vitro of Pneumocystis carinii with macrophages and L-cells. J. Exp. Med. 147:157-170.

19. Brinn, N. T. 1975. Rapid metallic histological staining. J. Histotechnol. $6: 125-129$

20. Cushion, M. T., and P. D. Walzer. 1984. Growth and serial passage of Pneumocystis carinii in A549 cell line. Infect. Immun. 44:245-251.

21. Bartlett, M. S., P. A. Vervanec, and J. W. Smith. 1979. Cultivation of Pneumocystis carinii with WI-38 cells. J. Clin. Microbiol. 10:796-799.

22. Kuroki, Y., R. J. Mason, and D. R. Voelker. 1988. Alveolar type II cells express a high-affinity receptor for pulmonary surfactant protein A. Proc. Natl. Acad. Sci. USA. 85:5566-5570.

23. Fornstedt, H. P., and J. Porath. 1975. Characterization studies on a new lectin found in seeds of Vicia ervilia. FEBS (Fed. Eur. Biochem. Soc.) Lett. 57:187-191.

24. Lowry, O. H., N. J. Rosebrough, A. L. Farr, and R. J. Randall. 1951. Protein measurement with the Folin phenol reagent. $J$. Biol. Chem. 193:265-275.

25. Bolton, A. E., and W. M. Hunter. 1973. The labelling of proteins to high specific radioactivities by conjugation to a ${ }^{125} \mathrm{I}$-containing acylating agent. Biochem. J. 133:529-539.

26. Proctor, R. A., D. F. Mosher, and P. J. Olbrantz. 1982. Fibronectin binding to Staphylococcus aureus. J. Biol. Chem. 257:14788-14794.

27. Durkin, M. M., M. S. Bartlett, S. F. Queener, M. M. Shaw, and J. W. Smith. 1989. A culture method allowing production of relatively pure Pneumocystis carinii trophozoites. J. Protozool. 36:31s-32s.

28. O'Farrell, P. H. 1975. High resolution two-dimensional electrophoresis of proteins. J. Biol. Chem. 250:4007-4021.

29. Towbin, H., T. Staehelin, and J. Gordon. 1979. Electrophoretic transfer of proteins from polyacrylamide gels to nitrocellulose sheets: procedure and some applications. Proc. Natl. Acad. Sci. USA. 76:4350-4354.

30. Scatchard, G. 1949. The attractions of proteins for small molecules and ions. Ann. NY Acad. Sci. 51:660-672.

31. King, R. J., D. Simon, and P. M. Horowitz. 1989. Aspects of secondary and quaternary structure of surfactant protein a from canine lung. Biochim. Biophys. Acta. 1001:294-301.

32. Haagsman, H. P., R. T. White, J. Schilling, K. Lau, B. J. Benson, J.
Golden, S. Hawgood, and J. A. Clements. 1989. Studies of the structure of lung surfactant protein SP-A. Am. J. Physiol. 257:L421-L429.

33. Stahl, P., P. H. Schlesinger, E. Sigardson, J. S. Rodman, and Y. C. Lee. 1980. Receptor-mediated pinocytosis of mannose glycoconjugates by macrophages: characterization and evidence for receptor recycling. Cell. 19:207-215.

34. Graves, D. C., S. J. N. McNabb, M. A. Worley, T. D. Downs, and M. H. Ivy. 1986. Analyses of rat Pneumocystis carinii antigens recognized by humans and rat antibodies by using western immunoblotting. Infect. Immun. 54:96-103.

35. Pesanti, E. L. 1987. Phospholipid profile of Pneumocystis carinii and its interaction with alveolar type II epithelial cells. Infect. Immun. 55:736-741.

36. Voss, T., H. Eistetter, and K. P. Schafer. 1988. Macromolecular organization of natural and recombinant lung surfactant protein SP 28-36. Structural homology with the complement factor Clq. J. Mol. Biol. 201:219-227.

37. Benson, B., S. Hawgood, J. Schilling, J. Clements, D. Damm, B. Cordell, and R. T. White. 1985. Structure of canine pulmonary surfactant apoprotein: cDNA and complete amino acid sequence. Proc. Natl. Acad. Sci. USA. 82:63796383.

38. White, R. T., D. Damm, J. Miller, K. Spratt, J. Schilling, S. Hawgood, B. Benson, and B. Cordell. 1985. Isolation and characterization of the human pulmonary surfactant apoprotein gene. Nature (Lond.). 317:361-363

39. Floros, J., R. Steinbrink, K. Jacobs, D. Phelps, R. Kriz, M. Recny, L. Sultzman, S. Jones, H. W. Taeusch, H. A. Frank, and E. F. Fritsch. 1986. Isolation and characterization of cDNA clones for the $35-\mathrm{kDa}$ pulmonary surfactantassociated protein. J. Biol. Chem. 261:9029-9033.

40. Sano, K., J. Fisher, R. J. Mason, Y. Kuroki, J. Schilling, B. Benson, and D. Voelker. 1987. Isolation and sequence of a cDNA clone for the rat pulmonary surfactant-associated protein (PSP-A). Biochem. Biophys. Res. Commun. 144:367-374.

41. Boggaram, V., K. Qing, and C. R. Mendelson. 1988. The major apoprotein of rabbit pulmonary surfactant. J. Biol. Chem. 263:2939-2947.

42. Ross, G. F., R. N. Notter, J. Meuth, and J. A. Whitsett. 1986. Phospholipid binding and biophysical activity of pulmonary surfactant-associated protein (SAP)-35 and its noncollagenous $\mathrm{COOH}$-terminal domains. J. Biol. Chem. 261:4283-4291.

43. Drickamer, K., M. A. Dordal, and L. Reynolds. 1986. Mannose-binding proteins isolated from rat liver contain carbohydrate-recognition domains linked to collagenous tails. J. Biol. Chem. 261:6878-6887.

44. Drickamer, K. 1989. Demonstration of carbohydrate-recognition activity in diverse proteins which share a common primary structure motif. Biochem. Soc. Trans. 17:13-15.

45. Sastry, K., G. A. Herman, L. Day, E. Deignan, G. Bruns, C. C. Morton, and R. A. B. Ezekowitz. 1989. The human mannose-binding protein gene exon structure reveals its evolutionary relationship to human pulmonary surfactant gene and localization to chromosome 10. J. Exp. Med. 170:1175-1189.

46. Ryan, R. M., R. E. Morris, W. R. Rice, C. Ciraolo, and J. Whitsett. 1989. Binding and uptake of pulmonary surfactant protein (SP-A) by pulmonary type II epithelial cells. J. Histochem. Cytochem. 37:429-440.

47. Wright, J. R., J. D. Borchelt, and S. Hawgood. 1989. Lung surfactant apoprotein SP-A (26-36 kDa) binds with high affinity to isolated alveolar type II cells. Proc. Natl. Acad. Sci. USA. 86:5410-5414.

48. King, R. J., M. C. Carmichael, and P. M. Horowitz. 1983. Reassembly of lipid-protein complexes of pulmonary surfactant. J. Biol. Chem. 258:1067210680.

49. Bloom, B. R. 1979. Games parasites play: how parasites evade immune surveillance. Nature (Lond.). 279:21-26.

50. Linke, M. J., M. T. Cushion, and P. D. Walzer. 1989. Properties of the major antigens of rat and human Pneumocystis carinii. Infect. Immun. 57:15471555

51. Menzel, J. E., J. S. Smolen, L. Liotta, and K. B. M. Reid. 1982. Interaction of fibronectin with $\mathrm{Clq}$ and its collagen-like fragment (CLF). FEBS (Fed. Eur. Biochem. Soc.) Lett. 129:188-192. 